DOI: https://doi.org/10.24127/ajpm.v9i4.3044

\title{
KEMAMPUAN METAKOGNITIF SISWA DALAM MENYELESAIKAN PERMASALAHAN PADA MATERI POLA BILANGAN DITINJAU DARI BRAIN DOMINANCE
}

\author{
Restu Lusiana $^{1}$, Wasilatul Murtafiah ${ }^{2 *}$, Firda Oktafian³ \\ 1,2*3 Pendidikan Matematika, Universitas PGRI Madiun, Jawa Timur, Indonesia \\ *Corresponding author \\ E-mail: $\quad$ restu.mathedu@unipma.ac.id ${ }^{1)}$ \\ wasila.mathedu@unipma.ac.id ${ }^{2 *}$ \\ firdaoktafian1998@gmail.com $^{3)}$
}

Received 18 August 2020; Received in revised form 26 November 2020; Accepted 16 December 2020

\begin{abstract}
Abstrak
Penelitian ini bertujuan untuk menganalisis kemampuan metakognitif siswa SMP dalam menyelesaikan permasalahan pada materi pola bilangan ditinjau dari brain dominance. Penentuan subjek berdasarkan brain dominance siswa kelas VIIIC SMP Negeri 13 Madiun. Berdasarkan angket brain dominance yang dibagikan diperoleh 4 subjek yang terdiri dari 2 subjek left brain dominance dan 2 subjek right brain dominance. Jenis penelitian yang digunakan adalah penelitian kualitatif. Teknik pengumpulan data dalam penelitian ini berdasarkan hasil angket, tes, dan wawancara. Teknik keabsahan data dilakukan dengan triangulasi teknik. Analisis data dilakukan dengan reduksi data, penyajian data, dan verifikasi data serta penarikan kesimpulan. Kesimpulan dari hasil penelitian ini adalah (1) subjek left brain dominance memenuhi tiga aspek memenuhi tiga aspek kemampuan metakognitif yaitu mengembangkan perencanaan, memonitor pelaksanaan dan mengevaluasi tindakan dan dari ketiga aspek yang termunculkan siswa dengan left brain dominance memiliki tingkat kemampuan metakognitif reflective use. (2) subjek rightt brain dominance memenuhi tiga aspek memenuhi tiga aspek kemampuan metakognitif yaitu mengembangkan perencanaan, memonitor pelaksanaan dan mengevaluasi tindakan dan dari ketiga aspek yang termunculkan siswa dengan right brain dominance memiliki tingkat kemampuan metakognitif aware use dan strategic use
\end{abstract}

Kata kunci: brain dominance; kemampuan metakognitif; penyelesaian masalah

\begin{abstract}
This study aims to analyze the metacognitive abilities of junior high school students in solving problems in the number pattern material in terms of brain dominance. In determining subjects based on brain dominance of VIIIC grade students of SMP Negeri 13 Madiun. Based on the brain dominance questionnaire distributed obtained 4 subjects consisting of 2 subjects left brain dominance and 2 subjects right brain dominance. The type of research used is qualitative research. Data collection techniques in this study are based on the results of questionnaires, tests, and interviews. The data validity technique is done by triangulation techniques. Data analysis was performed by data reduction, data presentation, and data verification and conclusion drawing. The conclusions from the results of this study are (1) the left brain dominance subject fulfills three aspects of fulfilling three aspects of metacognitive abilities namely developing planning, monitoring implementation and evaluating actions and of the three aspects that arise students with left brain dominance have a level of reflective use metacognitive ability. (2) the rightt brain dominance subject fulfills three aspects of meeting three aspects of metacognitive abilities, namely developing planning, monitoring implementation and evaluating actions and of the three aspects that arise students with right brain dominance have a level of metacognitive abilities aware of use and strategic use
\end{abstract}

Keywords: brain dominance; metacognitive ability; problem solving

This is an open access article under the Creative Commons Attribution 4.0 International License 


\section{PENDAHULUAN}

Salah satu tujuan pembelajaran matematika adalah agar siswa memiliki kemampuan mengembangkan aktivitas, kreatif dalam memecahkan masalah matematika, dan memahami konsep matematika (Kurniawati, 2017). Oleh karena itu perlu adanya sinkronisasi antara guru dengan tujuan pendidikan matematika di sekolah agar siswa memiliki kemampuan yang baik terutama ketika menyelesaikan masalah matematika (Sumartini, 2015; Murtafiah, Sa'dijah, Chandra, Susiswo, \& Zayyadi, 2020a; Murtafiah, Sa'dijah, Chandra, \& Susiswo, 2020b)

Penyelesaian masalah adalah proses yang dapat membantu seseorang untuk menjawab permasalahan dengan benar (Herlina, 2017; Restu Lusiana, 2017). Menurut Polya (Nurkhaffah \& Mahmudi, 2018) langkah penyelesaian masalah yaitu memahami masalah, menyusun rencana penyelesaian, melaksanakan rencana penyelesaian, dan memeriksa kembali.

Proses penyelesaian masalah berkaitan dengan kemampuan metakognitif siswa, dimana kemampuan metakognitif merupakan kesadaran seseorang akan pengetahuannya, tentang proses dan hasil berpikir serta kemampuannya dalam mengontrol dan mengevaluasi proses berpikir mereka sendiri (Nasution, Nasution, \& Haryati, 2018). Menurut (Waskitoningtyas, 2015) kemampuan metakognitif memiliki peranan penting dalam keberhasilan belajar siswa. Kebiasaan belajar dengan menggunakan kemampuan metakognitif menuntun siswa mampu menganalisis kebutuhan belajar, merumuskan tujuan belajar, dan merancang program belajar (Panggayuh, 2017). Selain itu, dengan kemampuan metakognitif siswa juga mampu memilih dan menerapkan strategi, memantau dan mengevaluasi apakah strategi telah dilaksanakan dengan benar, memeriksa hasil, serta merefleksi dan memperoleh umpan balik (Nugroho \& Dwijayanti, 2016).

Berdasarkan hasil observasi di SMPN 13 Madiun didapatkan informasi bahwa siswa kelas 8C SMPN 13 Madiun memiliki cara yang berbedabeda dalam menyelesaikan masalah pada materi pola bilangan. Hal tersebut terlihat dari cara siswa menentukan persamaan dari suatu barisan bilangan dan konfigurasi objek. Perbedaan cara berpikir atau pola berpikir siswa dalam menyelesaikan masalah matematika dipengaruhi oleh banyak faktor, beberapa diantaranya adalah kemampuan metakognitif dan brain dominance yang dimiliki oleh masingmasing siswa (Sukmaangara \& Prabawati, 2019).

Dalam proses penerimaan informasi, berpikir, dan menyelesaikan masalah ada kecenderungan bahwa manusia lebih sering menggunakan salah satu belahan otaknya. Hal ini oleh para ahli disebut dengan brain dominance. Brain dominance akan berpengaruh terhadap seseorang dalam menyerap informasi dalam belajar dan dalam memecahkan masalah (Kök, 2014). Faktor yang mempengaruhi keberhasilan peserta didik dalam penyelesaian masalah, salah satunya adalah sistem kerja otak (Sukmaangara \& Prabawati, 2019).

Menurut Wigati \& Sutriyono (2018) berdasarkan teori Split-Brain Roger Sperry, bahwa otak besar (cerebrum) adalah bagian yang memproses semua kegiatan intelektual kecerdasan otak manusia, pada teori tersebut juga dikemukakan bahwa otak besar dibagi menjadi dua, belahan otak kiri (brain's left hemisphere) dan belahan otak kanan (brain's right 
hemisphere). Belahan otak kiri cenderung memproses informasi berupa kata, angka, logika, analisis, daftar dan kemampuan menghitung, sedangkan belahan otak kanan cenderung memproses informasi berupa pemikiran konseptual, warna, irama, musik, visualspasial, gambar dan imajinasi serta kemampuan untuk menghasilkan ideide kreatif (Mansour, El-Araby, Pandaan, \& Gemeay, 2017). Brain dominance memberikan pengaruh terhadap cara berpikir dalam menyelesaikan masalah (R. Lusiana, Suprapto, Andari, \& Susanti, 2019).

Penelitian sebelumnya telah menganalisis tentang kemampuan metagognitif yang dikaitkan dengan prestasi belajar (Parlan, Astutik, \& Su'aidy, 2019). Penelitian lain juga membahas tentang kemampuan metakognitif siswa dalam memecahkan masalah (Budi M \& Ghofar CW, 2017; Pertiwi, Ahmadi, \& Fadly, 2018; Saputra \& Andriyani, 2018). Selain itu (Nurjanah, Milama, \& Fairusi, 2020) meneliti tentang level metakognitif siswa dalam menyelesaikan masalah. Namun belum diteliti tentang kemampuan metakognitif siswa dalam penyelesaian masalah.ditinjau dari brain dominance.

Tujuan penelitian ini adalah untuk menganalisis kemampuan metakognitif siswa dalam menyelesaikan permasalahan pada materi pola bilangan ditinjau dari brain dominance.

\section{METODE PENELITIAN}

Penelitian ini menggunakan metode penelitian kualitatif yaitu suatu prosedur penelitian yang menggunakan data berupa kata yang tertulis atau dari lisan objek yang diamati. Subjek dalam penelitian ini adalah seluruh siswa kelas VIII khususnya siswa kelas VIII C SMP
Negeri 13 Madiun yang berjumlah 20 siswa. Pengambilan subjek dilakukan melalui angket brain dominance. yang diberikan kepada seluruh siswa kelas VIII C secara online melalui google form.

Adapun instrumen penelitian yang digunakan pada penelitian ini adalah lembar observasi untuk mengamati secara langsung karakteristik siswa right brain dominance dan left brain dominance, angket brain dominance untuk mengidentifikasi brain dominance yang dimiliki masing-masing siswa, tes penyelesaian masalah berupa tes uraian tentang permasalahan pola bilangan untuk mengetahui kemampuan metakognitif siswa dalam menyelesaikan masalah, dan instrumen wawancara untuk mengetahui lebih dalam tentang kemampuan metakognitif siswa.

Teknik analisis data yang digunakan dalam penelitian ini adalah analisis data model interaktif Miles dan Huberman, yang meliputi reduksi data, penyajian data, verifikasi data, dan penarikan kesimpulan.

\section{HASIL DAN PEMBAHASAN}

Pengambilan subjek penelitian dilakukan melalui angket brain dominance yang diberikan kepada seluruh siswa kelas VIII C secara online melalui google form. Prosentase hasil analisis angket ditunjukkan pada gambar 1.

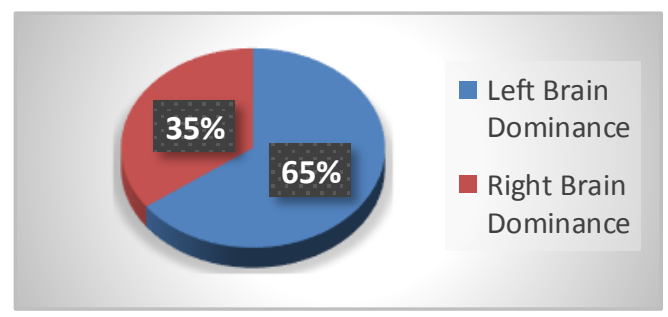

Gambar 1. Persentase Brain Dominance. 
DOI: https://doi.org/10.24127/ajpm.v9i4.3044

Berdasarkan hasil angket brain dominance didapatkan hasil seperti tampak pada Gambar 1 yaitu dari 20 siswa yang diberikan angket brain dominance, $65 \%$ tergolong left brain dominance dan $35 \%$ tergolong right brain dominance. Kemudian dari masing-masing kategori brain dominance dipilih 2 subjek left brain dominance dan 2 subjek right brain dominance sebagai sampel. Keempat subjek tersebut diberikan soal tes penyelesaian masalah materi pola bilangan.

Terdapat tiga indikator kemampuan metakognitif siswa yang dilihat dari cara penyelesaian soal yaitu mengembangkan memonitor pelaksanaan, dan mengevaluasi tindakan (Widadah, Afifah, \& Suroto, 2013). Berdasarkan dari soal tes yang telah dikerjakan dan hasil wawancara yang dilakukan diperoleh hasil sebagai berikut.

\section{Subjek left brain dominance}

Berdasarkan hasil pekerjaan

Subjek 1 dan 3 pada tes kemampuan

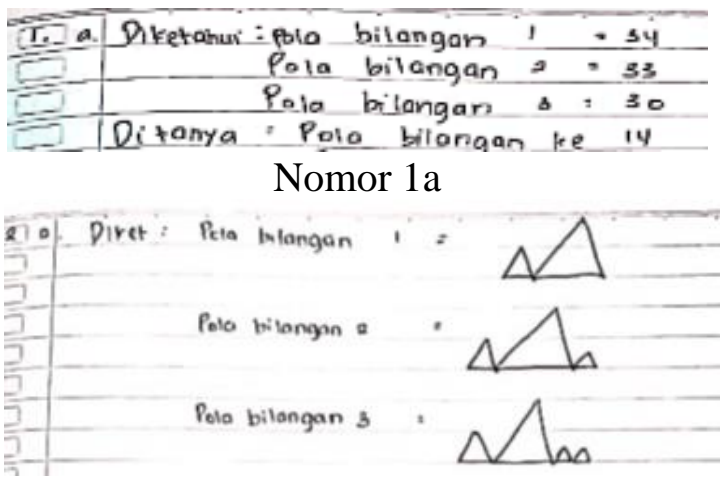

Nomor $2 \mathrm{a}$ siswa dalam menyelesaiakan masalah dapat dijabarkan kemampuan metakognitifnya sebagai berikut.

a. Mengembangkan Perencanaan

Dalam memahami masalah pada soal yang diberikan, Subjek 1 mencoba mengingat kembali materi yang pernah diajarkan terkait pola bilangan dan menemukan cara pengerjaannya. Setelah memahami masalah, Subjek 1 mulai menjelaskan apa saja yang diketahui dari soal secara rinci berurutan serta menjelaskan apa yang ditanyakan soal secara rinci dan berurutan. Selanjutnya Subjek 1 mulai menuliskan apa yang diketahui dari soal kedalam bentuk kalimat yang ringkas, terstruktur dan dituliskan secara tersusun kebawah yang berbentuk poinpoin penting sehingga akan memudahkan Subjek 1 dalam mengerjakan soal. Ketika Subjek 1 sudah memahami permasalahan dan menuliskan informasi yang terdapat pada soal, Subjek 1 sudah memiliki gambaran untuk penyelesaian. Hal ini dapat dilihat pada Gambar 2.

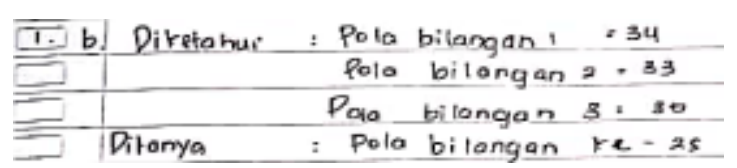
Nomor $1 b$

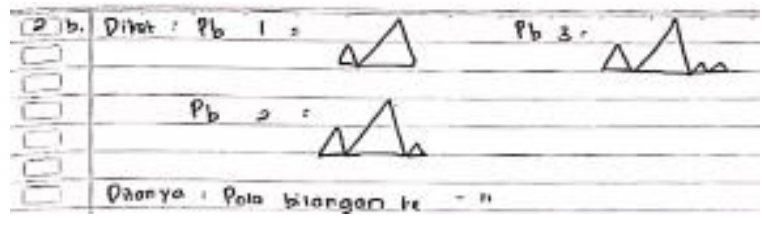

Nomor $2 b$

Gambar 2. Kemampuan Mengembangkan Perencanaan Subjek 1

Dalam memahami permasalahan pada soal yang telah diberikan Subjek 3 langsung dapat menyimpulkan akan menggunakan cara pembagian untuk menyelesaikan permasalahan pada soal seperti tampak pada Gambar 5. Setelah memahami masalah, Subjek 3 mulai menjelaskan apa saja yang diketahui dari soal secara rinci berurutan serta menjelaskan apa yang ditanyakan soal secara rinci dan berurutan. Selanjutnya Subjek 3 mulai menuliskan apa yang diketahui dari soal kedalam bentuk kalimat walaupun tidak dituliskan pada 
DOI: https://doi.org/10.24127/ajpm.v9i4.3044

semua soal dan hanya pada satu soal yaitu 2a serta penulisannya berupa kalimat dan tidak dibuat poin-poin. Ketika Subjek 3 sudah memahami permasalahan dan menuliskan informasi yang terdapat pada soal, Subjek 3 mengerjakan dengan cara yang telah direncanakan sebelumnya.

\section{a) Dikptahui acla 3 pola gambar yailu 2.3.4. Dicari bilangan pada pola re 7 Lalu seletan itu dilemukan cara dengan melaruran pembagtan yailu 7 yqng meruparan urutan ke?}

Gambar 3. Kemampuan Mengembangkan Perencanaan Subjek 3 Soal Nomor 2a

b. Memonitor Pelaksanaan

Dalam proses penyelesaian masalah Subjek 1 menuliskan menggunakan 2 cara yang berbeda meskipun Subjek 1 lebih nyaman menggunakan salah satu cara yaitu pembagian. Subjek 1 menuliskan secara rinci dan runtut mulai dari yang diketahui, ditanyakan, dan dijawab.

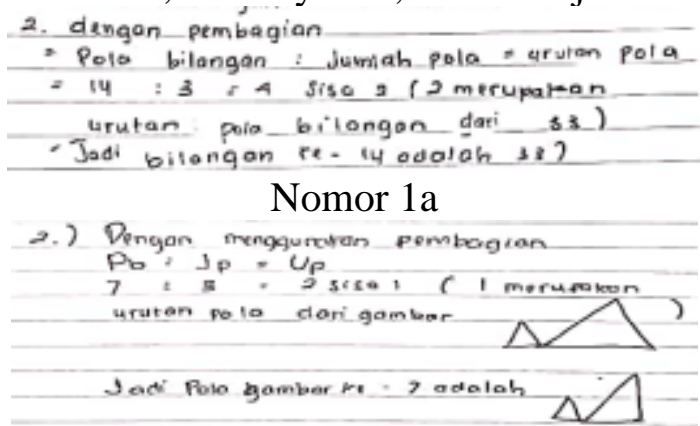

Nomor $2 \mathrm{a}$

Gambar 4. Kemampuan Memonitor Pelaksanaan Subjek 1
Kemudian Subjek 1 menyelesaikan permaslahan yang ada dengan menggunakan cara yang telah direncanakan sebelumnya sesuai dengan permasalahan yang ada dan meyakini bahwa cara yang digunakan beserta jawabannya sudah benar dan dapat dilihat pada Gambar 4.

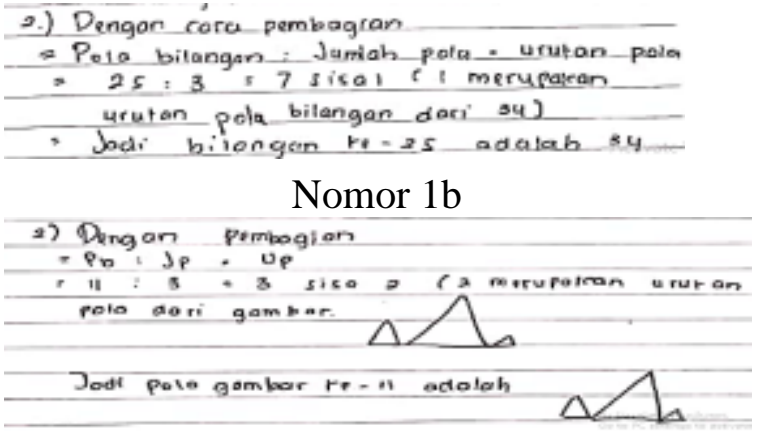

Nomor $2 b$

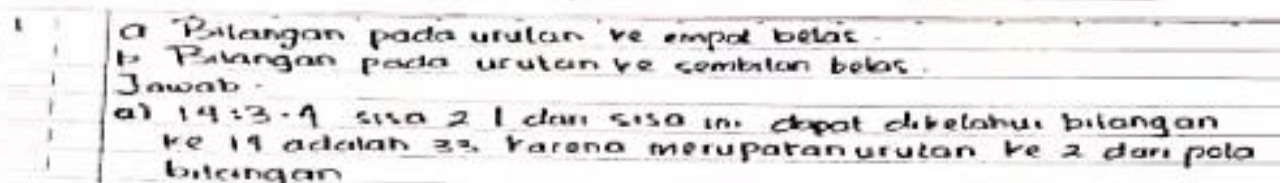

Gambar 5. Kemampuan Memonitor Pelaksanaan Subjek 3 Soal Nomor 1a

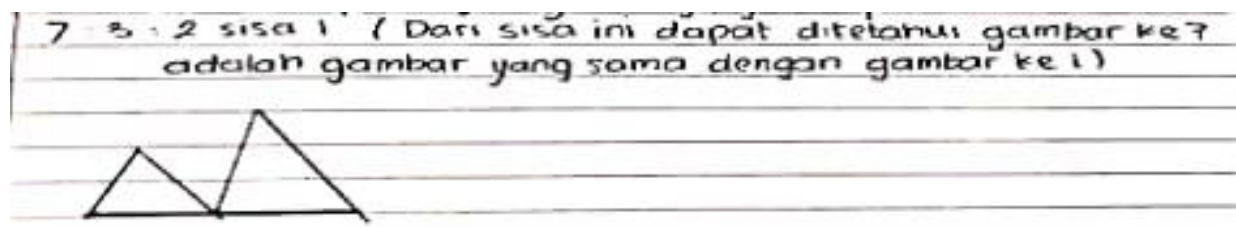

Gambar 6. 2 Kemampuan Memonitor Pelaksanaan Subjek 3 Soal Nomor 1b

\begin{abstract}
Dalam proses penyelesaian masalah Subjek 3 menuliskan menggunakan 2 cara yang berbeda tetapi tidak pada setiap soal misal pada nomor 1a pada Gambar 5, Subjek 3
\end{abstract}

menuliskan penyelesaian masalah dengan cara pembagian sedangkan pada soal nomor 1b pada Gambar 6, Subjek 3 menuliskan dengan cara mengurutkan dan Subjek 3 lebih nyaman 
DOI: https://doi.org/10.24127/ajpm.v9i4.3044

menggunakan salah satu cara yaitu pembagian karena menurutnya lebih simple. Subjek 3 menuliskan secara ringkas dan mayoritas hanya jawabannya saja hanya pada soal 2 a saja masih ditulis diketahui dan ditanyakan walaupun juga tidak runtut. Kemudian Subjek 3 menyelesaikan permasalahan yang ada dengan menggunakan cara yang telah direncanakan sebelumnya sesuai dengan permasalahan yang ada dan meyakini bahwa cara yang digunakan beserta jawabannya sudah benar walaupun menurut Subjek 3 masih ada keraguan dalam penulisan. c. Mengevaluasi Tindakan

Dalam proses mengevaluasi dari tindakan Subjek 1 mampu menjelaskan semua soal besrta jawabannya secara rinci dan runtut. Subjek 1 juga berpendapat bahwa semua soal secara garis besar memiliki cara pengerjaan yang sama. Subjek 1 mampu menjabarkan jawaban tidak hanya dengan 1 cara pengerjaan tetapi juga dapat menggunakan cara lain yang juga dijabarkan dalam jawabannya dan tampak pada Gambar 7, 8, 9, 10.

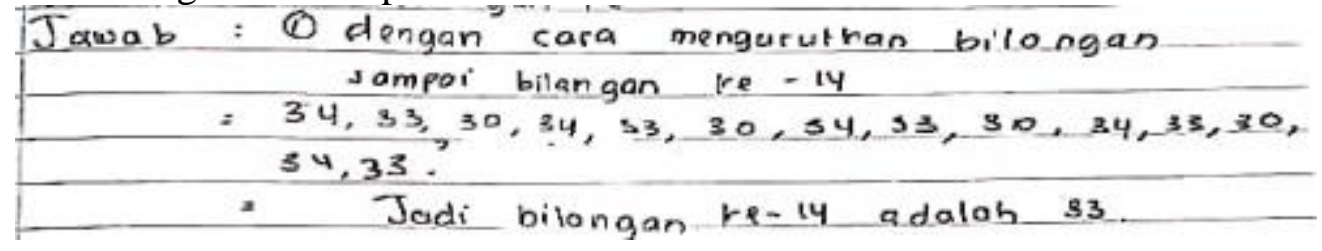

Gambar 7.3 Kemampuan Mengevaluasi Tindakan Subjek 1 Soal Nomor 1a

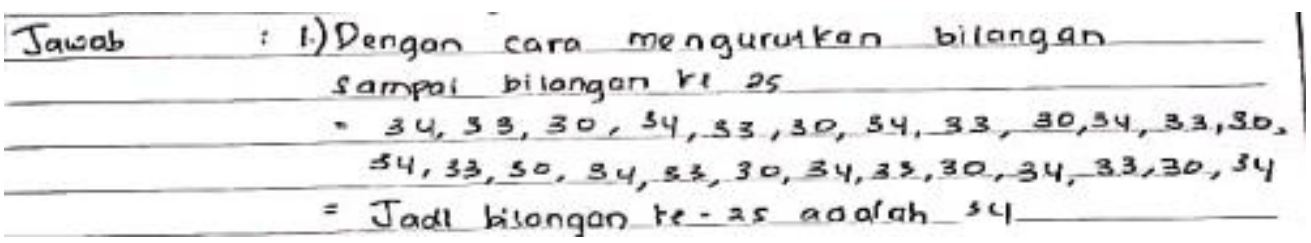

Gambar 8. Kemampuan Mengevaluasi Tindakan Subjek 1 Soal Nomor 1b

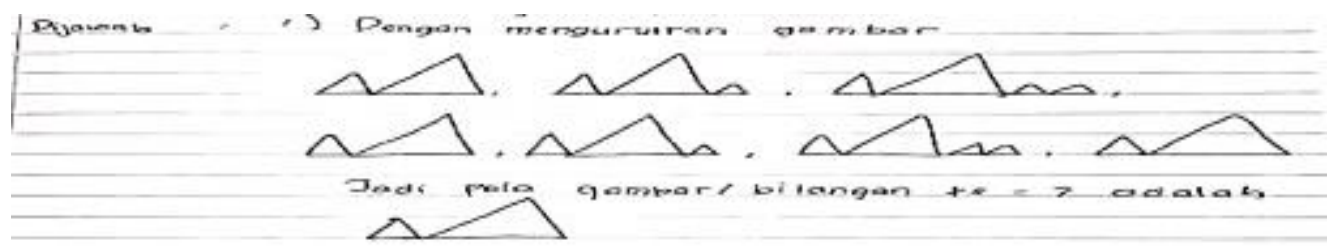

Gambar 9. Kemampuan Mengevaluasi Tindakan Subjek 1 Soal Nomor 2a

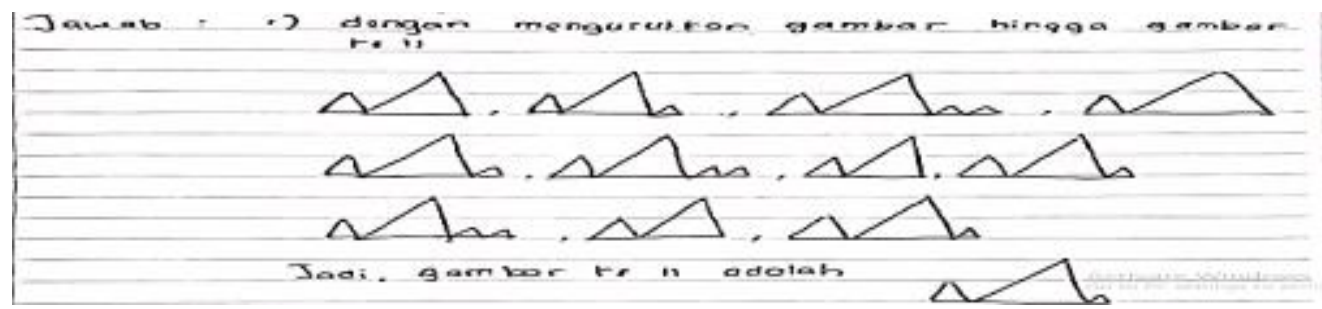

Gambar 10. Kemampuan Mengevaluasi Tindakan Subjek 1 Soal Nomor 2b

Dalam proses mengevaluasi dari tindakan Subjek 3 mampu menjelaskan soal beserta jawabannya secara rinci dan runtut. Subjek 3 berpendapat semua 
soal tes dapat diselesaikan dengan menggunakan cara yang sama. Subjek 3 mampu menjabarkan jawaban dengan 1 cara pengerjaan yaitu pembagian saat diminta menjelaskan dengan cara mengurutkan Subjek 3 berpendapat terlalu ribet tetapi dalam jawaban Subjek 3 tetap menuliskan cara lain yaitu mengurutkan. Hal ini tampak pada Gambar 11 dan 12.

b) Dengan menguruttan bilangan sampai te 25
$34,33,30.34 .33,30,34.33 .30,34.33,30,34.33,30,34.33$
$30,34.33 .30,34.33 .30,34$ (sehingga dilemutan dengan hasil 31 )

Gambar 41. Kemampuan Mengevaluasi Tindakan Subjek 3 Soal Nomor 1b

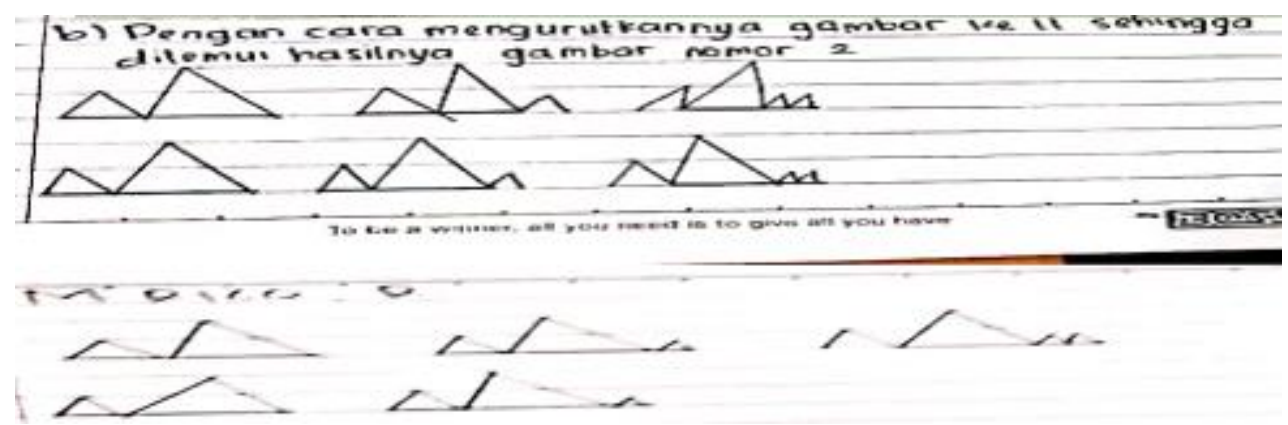

Gambar 12.5 Kemampuan Mengevaluasi Tindakan Subjek 3 Soal Nomor 2b

\section{Subjek right brain dominance}

Berdasarkan hasil pekerjaan

Subjek 2 dan 4 pada tes kemampuan siswa dalam menyelesaiakan masalah berikut disajikan kemampuan metakognitif subjek right brain dominance.

a. Mengembangkan Perencanaan

Dalam memahami permasalahan pada soal yang telah diberikan Subjek 2 mencoba mengingat kembali dengan membaca catatan pada materi pola bilangan semester sebelumnya. Setelah memahami masalah, Subjek 2 mulai menjelaskan apa saja yang diketahui dari soal secara rinci berurutan serta menjelaskan apa yang ditanyakan soal secara rinci dan berurutan. Selanjutnya Subjek 2 mulai menuliskan apa yang diketahui dari soal kedalam bentuk kalimat walaupun tidak dituliskan pada semua soal dan hanya pada satu soal serta penulisannya berupa kalimat dan tidak dibuat poin-poin. Ketika Subjek 2 sudah memahami permasalahan dan menuliskan informasi yang terdapat pada soal, Subjek 2 mengerjakan dengan cara yang telah direncanakan sebelumnya. Ini tampak pada Gambar 13.

2) a) Pola gambar Urutan ke-7
Diketahvi: pola gambor $2,3,4$
Difanya : Pola gambor vutan ke-7

Gambar 63. Kemampuan

Mengembangkan Perencanaan Subjek 2 Soal Nomor $2 \mathrm{a}$

Dalam memahami permasalahan pada soal yang telah diberikan Subjek 4 mengetahui cara penyelesaian nya namun kurang yakin dalam mengucapkannya. Setelah memahami masalah, Subjek 4 mulai menjelaskan apa saja yang diketahui dari soal secara singkat menjelaskan apa yang ditanyakan soal singkat. Selanjutnya Subjek 4 mulai menuliskan apa yang diketahui dari soal kedalam bentuk kalimat walaupun tidak dituliskan pada semua soal dan hanya pada satu soal yaitu 2a serta penulisannya berupa kalimat dan tidak dibuat poin-poin. 
DOI: https://doi.org/10.24127/ajpm.v9i4.3044

Ketika Subjek 4 sudah memahami permasalahan dan menuliskan informasi yang terdapat pada soal, Subjek 4 mengerjakan dengan cara yang telah direncanakan sebelumnya seperti tampak pada Gambar 14.

\begin{tabular}{|c|c|}
\hline 2. & Pola aprbar pada urutan ke? \\
\hline ב & Diketohui ado 3 pola gambor uatu $2,3,4$ \\
\hline$\exists$ & Dicari bilangan pada pola ke 7. Lolu seteloh it \\
\hline
\end{tabular}

Gambar 14.7 Kemampuan

Mengembangkan Perencanaan Subjek 4 Soal Nomor $2 \mathrm{a}$

b. Memonitor Pelaksanaan

Dalam proses penyelesaian masalah Subjek 2 menuliskan menggunakan 2 cara yang berbeda tetapi tidak pada setiap soal misal pada nomor 1a pada Gambar 15, Subjek 2 menuliskan penyelesaian masalah dengan cara pembagian sedangkan pada soal nomor $1 \mathrm{~b}$ Subjek 2 menuliskan dengan cara mengurutkan dan Subjek 2 lebih nyaman menggunakan salah satu cara yaitu mengurutkan. Subjek 2 menuliskan secara ringkas dan mayoritas hanya jawabannya saja hanya pada soal 2a saja masih ditulis diketahui dan ditanyakan walaupun juga tidak runtut. Kemudian Subjek 2 menyelesaikan permasalahan yang ada dengan menggunakan cara yang telah direncanakan sebelumnya sesuai dengan permasalahan yang ada dan meyakini bahwa cara yang digunakan beserta jawabannya sudah benar. Ini tampak pada Gambar 16.

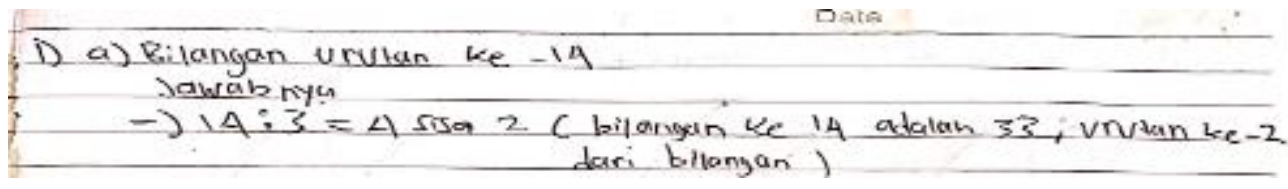

Gambar 15.8 Kemampuan Memonitor Pelaksanaan Subjek 2 Soal Nomor 1a

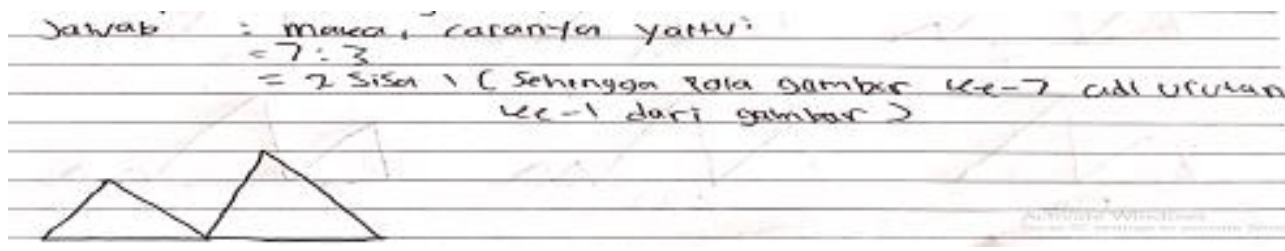

Gambar 16.9 Kemampuan Memonitor Pelaksanaan Subjek 2 Soal Nomor 2a

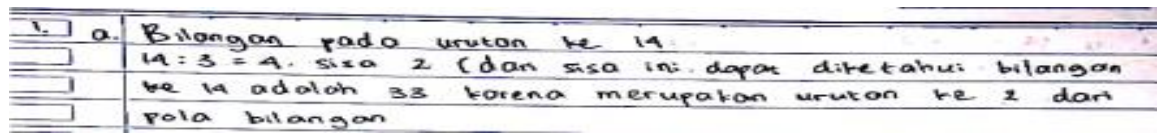

Gambar 17. Kemampuan Memonitor Pelaksanaan Subjek 4 Soal Nomor 1a

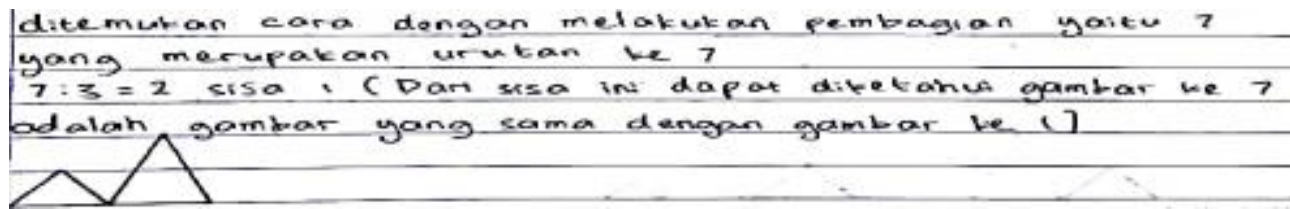

Gambar 18. Kemampuan Memonitor Pelaksanaan Subjek 4 Soal Nomor 2a

Dalam proses penyelesaian masalah Subjek 4 menuliskan menggunakan 2 cara yang berbeda tetapi tidak pada setiap soal misal pada nomor 1a pada Gambar 17, Subjek 4 menuliskan penyelesaian masalah 
DOI: https://doi.org/10.24127/ajpm.v9i4.3044

dengan cara pembagian sedangkan pada soal nomor 1b Subjek 4 menuliskan dengan cara mengurutkan dan Subjek 4 lebih nyaman menggunakan salah satu cara yaitu mengurutkan. Subjek 4 menuliskan secara ringkas dan mayoritas hanya jawabannya saja hanya pada soal 2a saja masih ditulis diketahui dan ditanyakan walaupun juga tidak runtut. Kemudian Subjek 4 menyelesaikan permasalahan yang ada dengan menggunakan cara yang telah direncanakan sebelumnya sesuai dengan permasalahan yang ada dan meyakini bahwa cara yang digunakan beserta jawabannya sudah benar dan tampak pada Gambar 18.

\section{c. Mengevaluasi Tindakan}

Dalam proses mengevaluasi dari tindakan Subjek 2 mampu menjelaskan soal beserta jawabannya secara rinci dan runtut. Subjek 2 berpendapat untuk menggunakan kedua cara yang ada agar Subjek 2 lebih menguasai kedua cara tersebut meskipun Subjek 2 lebih memilih cara mengurutkan. Subjek 2 mampu menjabarkan jawaban tidak hanya dengan 1 cara pengerjaan tetapi juga dapat menggunakan cara lain yang juga dijabarkan dalam jawabannya meskipun tidak terperinci dan tampak pada Gambar 19 dan 20.

Gambar 19. Kemampuan Mengevaluasi Tindakan Subjek 2 Soal Nomor 1b

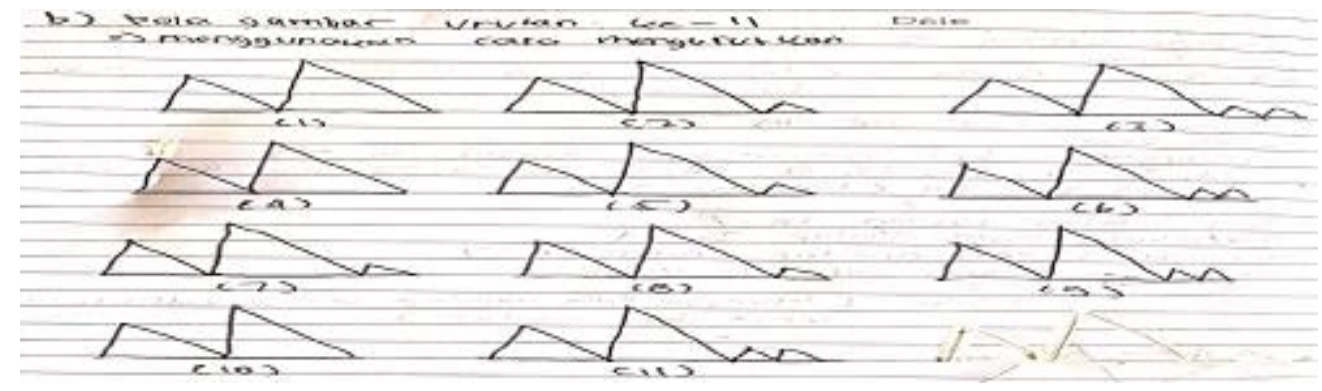

Gambar 100. Kemampuan Mengevaluasi Tindakan Subjek 2 Soal Nomor 2b

Dalam proses mengevaluasi dari tindakan Subjek 4 mampu menjelaskan menggunakan cara mengurutkan walaupun terlalu singkat dan belum pada kesimpulan jawaban. Subjek 4 berpendapat semua soal tes dapat diselesaikan dengan menggunakan cara yang sama tetapi mungkin juga bisa diselesaikan dengan cara yang berbeda tapi mungkin lebih sulit. Subjek 4 mampu menjabarkan jawaban dengan 1 cara pengerjaan yaitu mengurutkan saat diminta menjelaskan dengan cara mengurutkan Subjek 4 terlalu singkat menjabarkannya dan bahkan belum sampai ke kesimpulan jawaban dan tampak pada Gambar 21 dan 22.

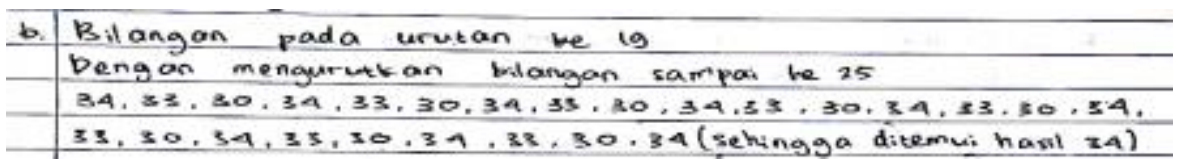

Gambar 111. Kemampuan Mengevaluasi Tindakan Subjek 4 Soal Nomor 1b 
DOI: https://doi.org/10.24127/ajpm.v9i4.3044

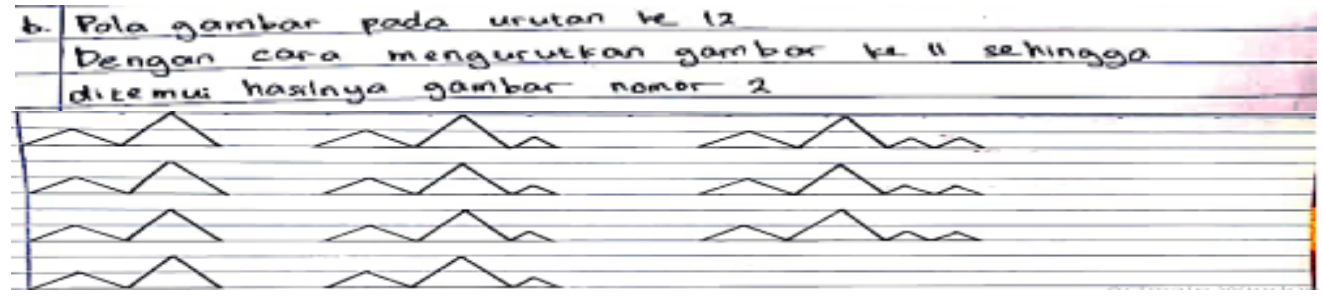

Gambar 22.12 Kemampuan Mengevaluasi Tindakan Subjek 4 Soal Nomor 1b

Siswa left brain dominance dalam mengembangkan perencanaan mampu melakukan perencanaan dengan menuliskan yang diketahui dan ditanyakan dari soal secara rinci dan runtut. Hal ini sejalan dengan penelitian Isroil, dkk (2017) dimana dalam menyelesaikan soal siswa mampu menuliskan yang diketahui dan ditanyakan. Misal dari soal 1a yang merupakan representasi barisan bilangan siswa dapat menuliskan yang diketahui yaitu pola bilangan 34, 33, dan 30 dan yang ditanyakan pola bilangan ke 14. Kemudian dari soal $2 \mathrm{a}$ yang merupakan representasi dari materi pola bilangan yaitu konfigurasi objek siswa dapat menuliskan dan menjelaskan dari pola gambar. Siswa left brain dominance mampu merancang perencanaan cara pengerjaan permasalahan pada soal materi pola bilangan dengan mengetahui cara yang harus dipakai dalam menyelesaikan permasalahan. Hal ini sejalan dengan penelitian Wigati \& Sutriyono (2018) yang menyebutkan bahwa siswa left brain dominance dominan dalam pembelajaran matematika. Hal ini dikarenakan siswa left brain dominance mampu merancang rencana penyelesaian terlebih dahulu dengan bisa menjelaskan apa yang diekahui dan ditanyakan yang merupakan tingkatan kemampuan metakognitif pada level reflective use seperti yang telah dikemukakan oleh Pamungkas (2018) dimana siswa dengan tingkat reflective use dapat mengemukakan permasalahan dan konsep dengan jelas dan tepat. Dengan demikian dimana reflective use menunjukkan siswa left brain dominance memiliki kemampuan metakognitif yang tinggi. Hal ini sejalan dengan penelitian Fauziah (2017) dimana siswa dengan kemampuan metakognitif tinggi hampir selalu membuat perancangan perencanaan dari masalah yang ada.

Dalam tahap memonitor pelaksanaan siswa left brain dominance mampu mengerjakan soal sesuai dengan cara yang telah direncanakan. Hal ini sejalan dengan penelitian Isroil (2017) siswa mampu menyelesaikan soal dengan cara yang telah direncanakan. Siswa mampu mengambil keputusan untuk menyelesaikan masalah yang dihadapi (Murtafiah, Sa'dijah, Chandra, $\&$ Susiswo, 2020c). Disini siswa dengan left brain dominance menuliskan pengerjaanya dengan menggunakan 2 cara yang berbeda yaitu cara pembagian dan mengurutkan. Tetapi siswa left brain dominance lebih memilih dengan cara pembagian yang menurut mereka lebih sederhana. Menurut (Yantoro, Susanti, \& Kurniawan, 2020) pembagian sendiri merupakan salah satu dari keterampilan berhitung dalam matematika. Hal ini sejalan dengan penelitian Wigati \& Sutriyono (2018) 
yang mana siswa left brain dominance cenderung dominan pada pembelajaran matematika. Disini siswa left brain dominance juga meyakini cara pengerjaanya yang dipilih benar adanya dari wawancara yang telah dilakukan.

Dalam mengevaluasi tindakan siswa left brain dominance mampu mengerjakan soal dengan cara lain. Seperti yang disebutkan di paragraf sebelumnya siswa left brain dominance menuliskan 2 cara yang berbeda seperti yang dikemukakan oleh Widadah, dkk (2013) dimana cara yang lain yaitu dengan mengurutkan selain dengan pembagian, hal ini sejalan dengan indikator mengevaluasi tindakan. Siswa left brain dominance mampu mengevaluasi tindakan dengan mampu menjelaskan pengerjaannya dari awal sampai menemukan jawabannya dengan menggunakan cara pembagian. Hal ini dikarenakan siswa left brain dominance memiliki tingkat kemampuan metakognitif pada tahap reflective use yang memungkinkan siswa dapat mengevaluasi langkah penyelesaian (Pamungkas, 2018). Dari hasil wawancara siswa left brain dominance mampu menerapkan cara yang sama pada soal yang lain dan mampu melihat kelebihan dan kekurangan dari cara pembagian dan mengurutkan hal ini sejalan dengan indikator mengevaluasi tindakan menurut Widadah, dkk (2013) dimana siswa mampu melihat kelebihan dan kekurangan serta mampu menerapkan cara yang sama pada soal yang lain.

Di sisi lain siswa right brain dominance dalam mengembangkan perencanaan dapat menuliskan yang telah dirancang sebelumnya dalam penyelesaian masalah pada soal materi pola bilangan. Siswa dengan right brain dominance mampu menuliskan diketahui dan ditanyakan dari soal meskipun tidak semua soal dan hanya soal 2a saja yang dimana diketahui untuk soal 2 a yaitu yang merupakan representasi dari materi pola bilangan konfigurasi objek siswa dapat menuliskan dan menjelaskan dari pola gambar 2,3,4 sedangkan pada soal nomor 1 yang merupakan soal materi pola bilangan barisan bilangan siswa right brain dominance tidak menuliskan yang diketahui dan ditanyakan. Siswa right brain dominance dapat merancang perencanaan sesuai dengan indikator kemampuan metakognitif. Menurut Widadah, dkk (2013) untuk mengerjakan soal pada materi pola bilangan namun tidak secara rinci dan runtut serta mayoritas jawaban yang ditulis langsung merujuk pada pengerjaan dan hasil jawabannya. Dari hasil wawancara siswa right brain dominance masih ada kekurangan ataupun salah dalam menjelaskan diketahui dan ditanyakan yang berarti siswa right brain dominance adalah siswa pada tingkat metakognitif aware use dan strategic use. Sesuai dengan pendapat Pamungkas (2018) dimana siswa mampu mengungkapkan sebagian permasalahan dan konsep namun masih terdapat sedikit kesalahan dalam menjelaskannya.

Dalam memonitor pelaksanaan siswa right brain dominance mampu mengerjakan soal sesuai dengan cara yang telah direncanakan. Disini siswa right brain dominance menuliskan pengerjaanya dengan menggunakan 2 cara yang berbeda yaitu cara pembagian dan mengurutkan. Tetapi siswa right brain dominance lebih memilih dengan cara mengurutkan yang membuat mereka lebih nyaman dalam mengerjakan soal tersebut hal ini sejalan dengan penelitian Wigati \& Sutriyono (2018) siswa right brain dominance mayoritas mengerjakan soal 
dengan cara mengurutkan. Melalui cara mengurutkan siswa right brain dominance mengimajinasikan yang mereka lihat pada soal serta lebih mengandalkan intuisi mereka dalam mengerjakan ini sejalan dengan pendapat (Ameen, 2017) dimana siswa dengan kecenderungan right brain dominance lebih mengandalkan imajinasi dan intuisi dalam proses berfikir. Siswa dengan right brain dominance meyakini cara pengerjaanya yang dipilih benar adanya dari wawancara yang telah dilakukan. Hal ini sejalan dengan salah satu indikator dalam memonitor pelaksanaan menurut Widadah, dkk (2013).

Dalam mengevaluasi tindakan siswa right brain dominance mampu mengerjakan soal dengan cara lain. Seperti yang disebutkan di paragraf sebelumnya siswa right brain dominance menuliskan 2 cara yang berbeda dimana cara yang lain yaitu dengan pembagian selain dengan mengurutkan hal ini sejalan dengan indiktor kemampuan metakognitif menurut Widadah, dkk (2013) dimana siswa mampu menyelesaikan soal dengan cara yang berbeda. Siswa right brain dominance dapat menjelaskan proses penyelesaian masalah dengan cara mengurutkan meskipun kurang rinci dan runtut serta masih terdapat beberapa kesalahan dalam menjelaskan, menurut Munawaroh (2018) hal ini wajar terdapat kesalahan dalam proses pembelajaran matematika bisa disebabkan ketidak telitian siswa dan sebab sebab lainnya. Tetapi dengan demikian siswa right brain dominance dapat menjelaskan dengan cara yang mereka peroleh ini sesuai dengan salah satu indikator mengevaluasi tindakan menurut Widadah, dkk (2013) yaitu memperhatikan cara kerja sendiri. Siswa right brain dominance ada pada tingkatan kemampuan metakognitif aware use dan strategic use dimana menurut Pamungkas (2018) pada langkah evaluasi siswa dengan tingkatan ini dapat melakukan evaluasi namun masih terdapat kesalahan. Hal ini dapat dilihat dari wawancara yang diperoleh dari siswa dengan right brain dominance.

Implikasi penelitian ini memperlihatkan adanya perbedaan kemampuan metakoknitif siswa dalam menyelesaikan masalah berdasarkan brain dominance yang dimiliki masingmasing siswa. Hal ini dapat digunakan guru sebagai bahan pertimbangan dalam merencanakan proses pembelajaran dan memilih media pembembelajaran sehingga mampu mengoptimalkan kemampuan metakognitif siswa terutama dalam menyelesaikan masalah berdasarkan brain dominance yang dimiliki oleh masing-masing siswa.

\section{KESIMPULAN DAN SARAN}

Berdasarkan pembahasan, dapat diambil kesimpulan bahwa siswa dengan left brain dominance mampu memenuhi tiga aspek kemampuan metakognitif yaitu mengembangkan perencanaan, memonitor pelaksanaan dan mengevaluasi tindakan. Dari ketiga aspek yang termunculkan siswa dengan left brain dominance memiliki tingkat kemampuan metakognitif reflective use yang merupakan kemampuan metakognitif dalam pembelajaran matematika. Hal ini dikarenakan dengan kecenderungan left brain dominance memiliki proses berpikir yang berhubungan dengan angka dan logika terbukti dari cara yang dipilih yaitu pembagian. Dapat disimpulkan jika siswa dengan left brain dominance memiliki kemampuan metakognitif reflective use. 
DOI: https://doi.org/10.24127/ajpm.v9i4.3044

Sedangkan siswa dengan right brain dominance mampu memenuhi tiga aspek kemampuan metakognitif yaitu mengembangkan perencanaan, memonitor pelaksanaan dan mengevaluasi tindakan. Dari ketiga aspek yang termunculkan siswa dengan right brain dominance memiliki tingkat kemampuan metakognitif aware use dan strategic use yang merupakan kemampuan metakognitif dalam pembelajaran matematika. Hal seperti ini dikarenakan dengan kecenderungan right brain dominance memiliki proses berpikir yang berhubungan dengan imajinasi dan intuisi terbukti dari cara yang dipilih yaitu mengurutkan. Dapat disimpulkan jika siswa dengan right brain dominance memiliki kemampuan metakognitif yang aware use dan strategic use.

Berdasarkan hasil penelitian dapat disampaikan saran sebagai upaya mengembangkan hasil penelitian yang serupa diantaranya: (1) pada penelitian selanjutnya hendaknya dilakukan tahap pra penelitian untuk memastikan siswa yang akan dijadikan subjek penelitian memiliki right brain dominance atau left brain dominance untuk meningkatkan kredibilitas hasil penelitian, (2) dalam menyebarkan angket kepada siswa hendaknya dilakukan lebih dari 1 kali untuk melihat konsistensi brain dominance yang dimiliki oleh masing-masing siswa.

\section{DAFTAR PUSTAKA}

Ameen, A. (2017). A study of right and left brain dominant students at IB\&M with respect to their gender, age and educational background. International Journal of Advances in Scientific Research, 3(9), 115. https://doi.org/10.7439/ijasr.v3i9.4 334
Budi M, I., \& Ghofar CW, A. (2017). Analisis Keterampilan Berpikir Kritis Dan Metakognitif Mahasiswa Program Studi Pendidikan Biologi. BIOMA Jurnal Ilmiah Biologi, 6(1). https://doi.org/10.26877/bioma.v6i 1.1472

Fauziah, A. F. (2017). Analisis Kemampuan Metakognitif Siswa Dalam Mengerjakan Soal Pemecahan Masalah Matematika Di Sekolah Menengah Pertama.

Herlina, K. (2017). Development of Optics Learning Model to Build Mental Models and Problem Solving Ability. Atlantis Press, 57(ICMSEd 2016), 53-59.

Isroil, A., Budayasa, I. K., \& Masriyah, M. (2017). Profil Berpikir Siswa SMP dalam Menyelesaikan Masalah Matematika Ditinjau dari Kemampuan Matematika. Jurnal Review Pembelajaran Matematika, 2(2), 93-105. https://doi.org/10.15642/jrpm.2017 .2.2.93-105

Kök, İ. (2014). Listening Comprehension Achievement and Brain Dominance. Procedia Social and Behavioral Sciences, 122, 329-334. https://doi.org/10.1016/j.sbspro.20 14.01.1348

Kurniawati, E., Hartono, \& Zamzaili. (2017). Pengaruh Model Pembelajaran Assurance, Relevance, Interest, Assesment, Satisfaction (ARIAS) Integratif Dan Kemampuan Awal Dalam Meningkatkan Pemahaman Konsep Dan Pemecahan Masalah Matematika Siswa Sekolah Menengah Pertama Di Kepahiang. Jurnal Pendidikan Matematika Raflesia, 2(2), 174-187. 
Lusiana, R., Suprapto, E., Andari, T., \& Susanti, V. D. (2019). The influence of right and left brain intelligence on mathematics learning achievement. Journal of Physics: Conference Series, 1321(3).

https://doi.org/10.1088/1742-

6596/1321/3/032122

Lusiana, Restu. (2017). Analisis

Kesalahan Mahasiswa Dalam Memecahkan Masalah Pada Materi Himpunan Ditinjau Dari Gaya Kognitif. Jurnal Penelitian Dan Pembelajaran Matematika, 10(1), 24-29.

https://doi.org/10.30870/jppm.v10i 1.1290

Mansour, E. A., El-Araby, M., Pandaan, I. N., \& Gemeay, E. M. (2017). Hemispherical Brain Dominance and Academic Achievement among Nursing Students. IOSR Journal of Nursing and Health Science, $\quad$ 06(03), 32-36. https://doi.org/10.9790/19590603083236

Munawaroh, N., Rohaeti, E. E., \& Aripin, U. (2018). Analisis Kesalahan Siswa Berdasarkan Kategori Kesalahan Menurut Watson dalam Menyelesaikan Soal Komunikasi Matematis Siwa SMP. JPMI (Jurnal Pembelajaran Matematika Inovatif), 1(5), 993. https://doi.org/10.22460/jpmi.v1i5. p993-1004

Murtafiah, W., Sa'dijah, C., Chandra, T. D., Susiswo, \& Zayyadi, M. (2020a). Novice and Experienced Mathematics Teachers 'Decision Making Process in Designing Math Problem. IOP Conf. Series: Journal of Physics: Conf. Series, 1464(012030), 1-6. https://doi.org/10.1088/17426596/1464/1/012030
Murtafiah, W., Sa'dijah, C., Chandra, T. D., \& Susiswo. (2020b). Exploring the Types of Problems Task by Mathematics Teacher to Develop Students' HOTS. In AIP Conference Proceedings 2215 (Vol. 060018, pp. 1-7).

Murtafiah, W., Sa'dijah, C., Chandra, T. D., \& Susiswo. (2020c). Decision Making of Prospective Mathematics Teacher in Designing of Cartesian coordinate Teaching. IOP Conf. Series: Journal of Physics: Conf. Series, 1-7.

Nasution, M. D., Nasution, E., \& Haryati, F. (2018). Pengembangan Bahan Ajar Metode Numerik Dengan Pendekatan Metakognitif Berbantuan Matlab. Mosharafa: Jurnal Pendidikan Matematika. https://doi.org/10.31980/mosharafa .v6i1.295

Nugroho, A. A., \& Dwijayanti, I. (2016). Proses Berpikir Mahasiswa Ditinjau Dari Dari Kemampuan Metakognitif Awal Dalam Pemecahan Masalah Matematis. Jurnal Pendidikan Dan Pembelajaran Matematika, 9(1), 25-32.

Nurjanah, A. I., Milama, B., \& Fairusi, D. (2020). Students' Metacognitive Awareness and Reading Comprehension of Narrative Texts. IJEE (Indonesian Journal of English Education), 7(1), 73-86. https://doi.org/10.15408/ijee.v7i1.1 7027

Nurkhaffah, P. S., \& Mahmudi, A. (2018). Efektivitas Pembelajaran CTL Berbasis Pemecahan Masalah Model Polya Terhadap Kemampuan Pemecahan Masalah Siswa Effectiveness. Jurnal Pendidikan Matematika Dan Sains, 7(1), 3 . 
Pamungkas, Z. S., Aminah, N. S., \& Nurosyid, F. (2018). Analisis Kemampuan Berpikir Kritis Siswa dalam Menyelesaikan Soal Literasi Sains Berdasarkan Tingkat Kemampuan Metakognisi. Edusains, 10(2), 254-264.

Panggayuh, V. (2017). Pengaruh Kemampuan Metakognitif

Terhadap Prestasi Akademik Mahasiswa Pada Mata Kuliah Pemrograman Dasar. JIPI (Jurnal Ilmiah Penelitian Dan Pembelajaran Informatika), 2(1), 20-25.

Parlan, P., Astutik, N. A. I., \& Su'aidy, M. (2019). Analisis Pengetahuan Metakognitif Dan Kesadaran Metakognitif Peserta Didik Serta Hubungannya Dengan Prestasi Belajarnya Pada Materi Larutan Penyangga. J-PEK (Jurnal Pembelajaran Kimia), 4(1), 1-13. https://doi.org/10.17977/um026v4i 12019p001

Pertiwi, F. N., Ahmadi, A., \& Fadly, W. (2018). Analisis Tingkat Kemampuan Metakognitif Mahasiswa Melalui Mai (Metacognitive Awareness Inventory) Pada Eksperimen Berbasis Problem Solving. Kodifikasia, $\quad 12(1), \quad 35$. https://doi.org/10.21154/kodifikasi a.v12i1.1417

Saputra, N. N., \& Andriyani, R. (2018). Analisis Kemampuan Metakognitif Siswa Sma Dalam Proses Pemecahan Masalah. AKSIOMA: Jurnal Program Studi Pendidikan Matematika, $\quad 7(3), \quad 473$. https://doi.org/10.24127/ajpm.v7i3. 1403

Sukmaangara, B., \& Prabawati, M. N. (2019). Analisis struktur berpikir peserta didik dalam menyelesaikan masalah tes kemampuan berpikir kritis matematik berdasarkan dominasi otak. In Prosiding Seminar Nasional \& Call For Papers (pp. 89-95).

Sumartini, T. S. (2015). Peningkatan Kemampuan Penalaran Matematis Siswa Melalui Pembelajaran Berbasis Masalah. Jurnal Pendidikan Matematika, 5, 2.

Waskitoningtyas, R. S. (2015). Pembelajaran matematika dengan kemampuan metakognitif berbasis pemecahan masalah kontekstual mahasiswa pendidikan matematika Universitas Balikpapan. Math Didactic: Jurnal Pendidikan Matematika.

https://doi.org/10.33654/math.v1i3. 21

Widadah, S., Afifah, D. S. N., \& Suroto. (2013). Profil Metakognisi Siswa Dalam Menyelesaikan Soal Sistem Persamaan Linear Dua Variabel Berdasarkan Gaya Kognitif (Metakognisi's Profile Student in Solve Equation System Problem Linear Two Variable Bases To Inspire Kognitif). Jurnal Pendidikan Matematika STKIP PGRI Sidoarjo ISSN: 2337-8166, 1(1), 13-24.

Wigati, \& Sutriyono. (2018). Deskripsi Penggunaan Otak Kiri Dan Otak Kanan Pada Pembelajaran Matematika Materi Pola Bagi Siswa SMP. Jurnal Mitra Pendidikan, 2(1), 11-22.

Yantoro, Susanti, E. P., \& Kurniawan, A. R. (2020). Problema Guru dalam Mengajarkan Berhitung Pembegian di Kelas Rendah Sekolah Dasar. MUBTADI, 2(1), 51-59. 